\title{
Light and Scanning Electron Microscopic Studies on the Intestine of Grass Carp (Ctenopharyngodon idella): II-Posterior Intestine
}

\author{
Mokhtar DM*, Abd-Elhafez EA and Hassan AH
}

Faculty of Veterinary Medicine, Department of Anatomy and Histology, Assuit University, 71526, Egypt

\begin{abstract}
The present study was done in order to demonstrate the histological, histochemical as well as surface architecture of the posterior intestine of grass carp. The epithelium of posterior intestine was constituted of enterocytes (simple columnar epithelium), goblet cells, enteroendocrine cells and lymphocytes. The enterocytes were characterized by numerous large vesicles, which may represent pinocytotic activity to some nutrients. The goblet cells gave positive reaction to both PAS and Alcian blue, in addition to presence of metachromatic substances by toluidine blue. The lamina propria-sub mucosa was consisted of loose connective tissue with abundant collagen and elastic fibers.
\end{abstract}

Keywords: Pinocytosis; Enterocytes; Intestine; Scanning electron microscopy

\section{Introduction}

The intestinal mucosa of most teleost is formed of enterocytes and mucous cells. Many authors had focused on the importance of muco-substances present in fish intestinal tract and correlated these with the absorption and transportation of macromolecules, increase of digestive efficiency, buffering of intestinal fluid as well as prevention of proteolytic damage of the epithelium and defense against bacteria and other pathogens [1-6].

Grass carp have been extensively cultured in many areas of the world. It is fast growing herbivorous fish; it usually feeds on grasses or other aquatic vegetation and can be grown together with other fish species [7].

The aim of the present study is to describe the histological as well as surface architecture of the posterior intestine of grass carp (Ctenopharyngodon idella). This study may provide a basis for future studies of digestion and absorption of this economic fish species.

\section{Materials and Methods}

\section{Source of samples}

The materials employed in this study consisted of randomly obtained 20 adult specimens of both sex of the grass carp (Ctenopharyngodon idella). The materials were collected from fish farm in El-Minea during the year. The specimens were $37.20 \pm 4.0 \mathrm{~cm}$ in standard length and $421.60 \pm 8.70$ gm in body weight.

\section{Histological analysis}

The samples for histological examination were dissected as soon as possible from posterior portion of intestine of grass carp through a middle incision in the abdominal cavity. All samples were dissected at $1 \times 1 \times 0.05 \mathrm{~cm}$ and were immediately fixed in Bouin's fluid for 22 hours. The fixed materials were dehydrated in an ascending series of ethanol, cleared in methyl benzoate and then embedded in paraffin wax. Transverse and longitudinal paraffin sections at 5-8 $\mu \mathrm{m}$ in thickness were cut and stained with Harris haematoxylin and Eosin for general histological examination, Wigert's Elastica for elastic fibers, Crossmon's trichrome for collagenous fibers and Grimelius silver method foe enteroendocrine cells [8].

\section{Histochemical analysis}

Representative sections were stained with Alcian blue for detection of acid mucosubstances, PAS for neutral mucins and combined alcian blue-PAS technique for acid and neutral mucins.

\section{Semi-thin sections}

Small pieces 2.0-3.0 $\mathrm{mm}$ long from posterior portion of intestine of grass carp were placed in $2.5 \%$ cold glutaraldehyde in phosphate buffer ( $\mathrm{pH}$ 7.2) for $24 \mathrm{hrs}$. The pieces were washed twice in $0.1 \mathrm{M}$ phosphate buffer and then post-fixed in $1 \%$ osmium tetraoxide, in the same buffer. The post-fixed pieces were dehydrated in graded alcohols and embedded in araldite resin. Thin sections $(1 \mu \mathrm{m})$ in thickness were stained with $1 \%$ toluidine blue.

\section{Scanning electron microscopy}

Formaldehyde- fixed specimens of posterior intestine of grass carp were washed in $0.1 \mathrm{M}$ cacodylate buffer for $1 \mathrm{~h}$.Then transferred to a $1 \%$ solution of tannic acid for $2 \mathrm{~h}$ at room temperature. The pieces then were washed again in buffer and post fixed for $2 \mathrm{~h}$ in $1 \%$ osmium tetraoxide. The post fixed materials were washed, dehydrated in a series of increasingly concentrated solutions. They were then mounted on aluminum stubs and sputter- coated with gold/palladium for $3 \mathrm{~min}$. The specimens were examined with a JEOL. JSM-5400 LV Scanning Electron Microscope.

\section{Morphometrical measurements}

Morphometric study was applied on representative stained sections of the posterior intestine by using Image analysis system (Leica Q500MC). Including: -Diameter of the posterior intestine.

*Corresponding author: Mokhtar DM, Faculty of Veterinary Medicine, Department of Anatomy and Histology, Assuit University, Egypt, 71526, Tel: 20882423333; E-mail: doaamokhtar33@yahoo.com

Received June 18, 2015; Accepted July 27, 2015; Published August 31, 2015

Citation: Mokhtar DM, Abd-Elhafez EA, Hassan AH (2015) Light and Scanning Electron Microscopic Studies on the Intestine of Grass Carp (Ctenopharyngodon idella): II-Posterior Intestine. J Aquac Res Development 6: 380. doi:10.4172/2155 9546.1000380

Copyright: (c) 2015 Mokhtar DM, et al. This is an open-access article distributed under the terms of the Creative Commons Attribution License, which permits unrestricted use, distribution, and reproduction in any medium, provided the original author and source are credited. 
Citation: Mokhtar DM, Abd-Elhafez EA, Hassan AH (2015) Light and Scanning Electron Microscopic Studies on the Intestine of Grass Carp (Ctenopharyngodon idella): II-Posterior Intestine. J Aquac Res Development 6: 380. doi:10.4172/2155-9546.1000380

\begin{abstract}
-Thickness of the wall
-Diameter of the lumen

-Thickness of the tunica mucosa

-Height and width of the mucosal folds

-Height of the surface epithelium

-Thickness of the submucosa

-Thickness of the tunica mucularis
\end{abstract}

\section{Results}

The mean diameter of the posterior intestine was $4291.20 \pm 42.10$ $\mu \mathrm{m}$, the mean thickness of the wall was $1320.35 \pm 10.29 \mu \mathrm{m}$ and the mean diameter of the lumen was $1650.50 \pm 42.37 \mu \mathrm{m}$, which represented $28.62 \%$ of the diameter of the organ (Table 1). Light microscopic observations revealed that the wall of posterior intestine of grass carp was composed of tunica mucosa, tunica sub mucosa, tunica muscularis and tunica serosa.

\section{Tunica mucosa}

Its mean thickness was $925.09 \pm 22.63 \mu \mathrm{m}$ that constituted $70.06 \%$ of the thickness of the wall. The number of mucosal folds reached about 24 folds/cross section (Table 1). The mucosal folds appeared slender and slightly wavy (Figure 1A). The mean height of the folds was 902.45 $\pm 5.22 \mu \mathrm{m}$, which constituted about $68.34 \%$ of the thickness of the wall, while their mean width was $204.51 \pm 10.71 \mu \mathrm{m}$ (Table 1).

\section{Lamina epithelialis}

Its mean height was $46.04 \pm 0.77 \mu \mathrm{m}$, which represented about $3.48 \%$ of the thickness of the wall (Table 1). It consisted of tall simple columnar absorptive cells (enterocytes) with oval vesicular nucleus situated nearly in the middle region. These columnar cells carried microvilli. Small lymphocytes were scattered in the basal part of the epithelium (Figure 1B).

Histochemical analysis revealed that the goblet cells were numerous and stained intensely positive with Alcian blue and combined alcian blue- PAS (Figure 2A and 2B). Also these cells showed positive reaction for neutral mucosubstances by PAS (Figure 2C). Many ovoid-shaped

\begin{tabular}{|c|c|}
\hline Measurements & $\begin{array}{c}\text { posterior intestine of grass } \\
\text { carp }\end{array}$ \\
\hline Diameter of the organ $(\mu \mathrm{m})$ & $4291.20 \pm 42.10$ \\
\hline Thickness of the wall $(\mu \mathrm{m})$ & $1320.35 \pm 10.29$ \\
\hline Diameter of the lumen $(\mu \mathrm{m})$ & $1650.50 \pm 42.37$ \\
& $38.46 \%$ \\
\hline Thickness of mucosa $(\mu \mathrm{m})$ & $925.09 \pm 22.63$ \\
& $70.06 \%$ \\
\hline Number of mucosal folds/cross section & $24.17 \pm 4.11$ \\
\hline Height of mucosal folds $(\mu \mathrm{m})$ & $902.45 \pm 5.22$ \\
& $68.34 \%$ \\
\hline Width of mucosal folds $(\mu \mathrm{m})$ & $204.51 \pm 10.71$ \\
\hline Height of the epithelium $(\mu \mathrm{m})$ & $46.04 \pm 0.77$ \\
& $3.48 \%$ \\
\hline Thickness of submucosa $(\mu \mathrm{m})$ & $109.35 \pm 5.72$ \\
& $8.28 \%$ \\
\hline Thickness of muscularis $(\mu \mathrm{m})$ & $311.72 \pm 2.66$ \\
\hline
\end{tabular}

Table 1: Morphometrical measurements of posterior intestine of grass carp as well as their relation (\%) to the wall measurements.

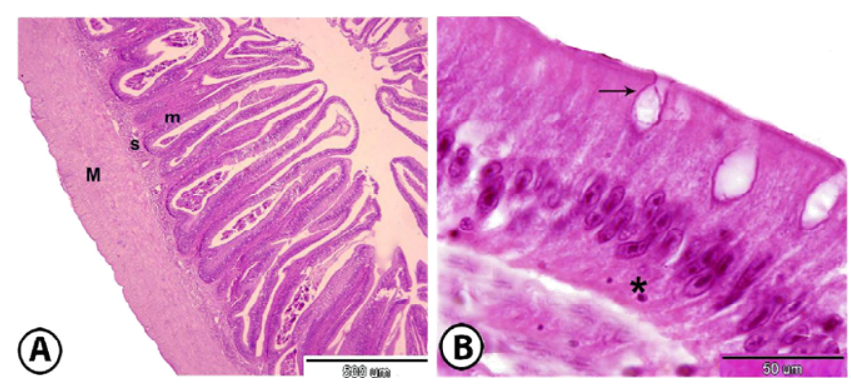

Figure 1: Histological analysis of posterior intestine of grass carp stained with $\mathrm{HE}(\mathrm{A})$ : the wall of posterior intestine of grass carp showing folded mucosa $(\mathrm{m})$,submucosa $(\mathrm{S})$ and muscularis (M). (B): Photomicrograph of the simple columnar epithelium of posterior intestineof grass carp with goblet cells (arrow). Note presence of lymphocytes in the basal part of the epithelium (asterisk).

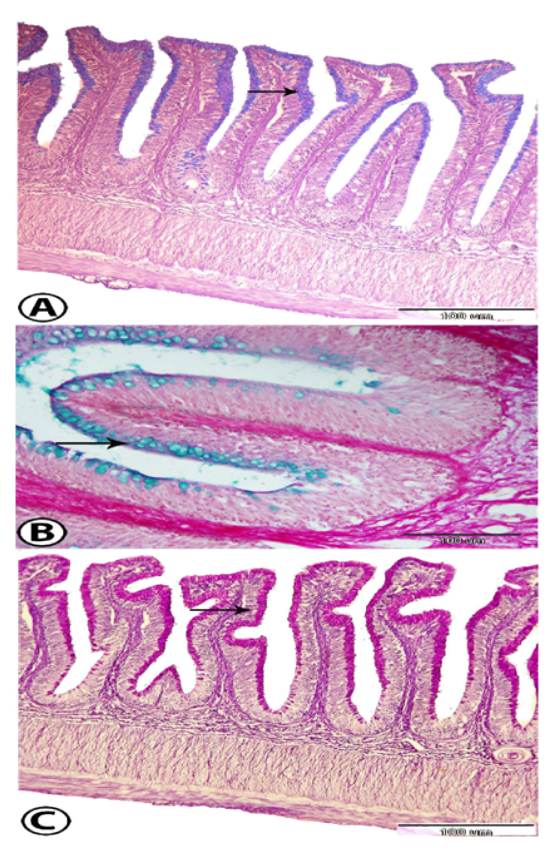

Figure 2: Histochemical analysis of goblet cells of posterior intestine of grass carp. (A) Numerous Alcian blue positive goblet cells (arrow). (Combined AB and PAS). (B) Higher magnification of the goblet cells (arrow) that reacted positively foralcian blue (alcian blue/Van Gieson). (C) Photomicrograph of the posterior intestine of grass carp showing numerous PAS positive goblet cells (arrow) (PAS).

enteroendocrine cells were distributed in the epithelium of posterior intestine among the enterocytes (Figure 4A).

\section{Lamina propria}

It was formed of connective tissue layer that was extended into the mucosal folds. It contained blood capillaries and elastic fibers (Figure $3 \mathrm{~A}$ ), collagenous fibers, smooth muscle cells (Figure 3B).

\section{Tunica submucosa}

It was connective tissue layer contained thick parallel collagenous fibers (Figure 1B) and distinct elastic fibers with blood capillaries (Figure 3A). The submucosa thickness was $109.35 \pm 5.72 \mu \mathrm{m}$, which represented $8.28 \%$ of the thickness of the wall (Table 1 ). 
Citation: Mokhtar DM, Abd-Elhafez EA, Hassan AH (2015) Light and Scanning Electron Microscopic Studies on the Intestine of Grass Carp (Ctenopharyngodon idella): II-Posterior Intestine. J Aquac Res Development 6: 380. doi:10.4172/2155-9546.1000380

Page 3 of 5

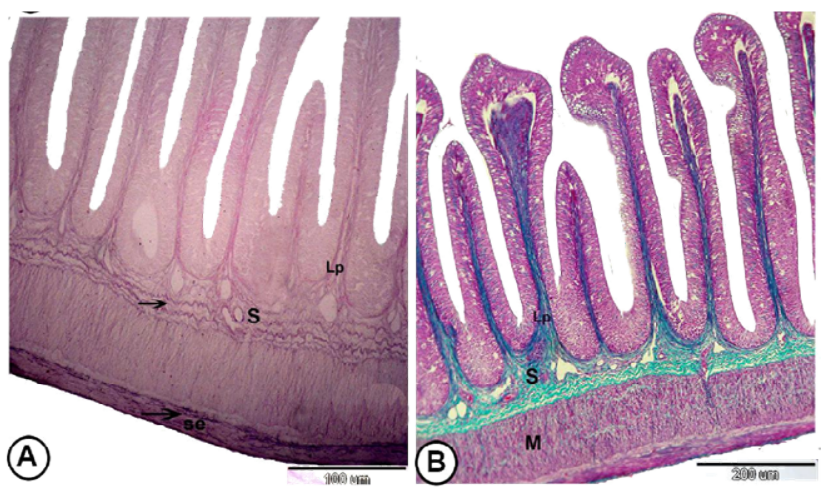

Figure 3: The wall of the posterior intestine: (A) Photomicrograph of the posterior intestine of grass carp showing presenceof elastic fibers (arrows) in lamina propria (Lp), submucosa (S) and thick serosa (se). (Weigert's Elastica, $X$ 200). (B): Photomicrograph of the posterior intestine of grass carp showing laminapropria (Lp) and submucosa (S) stained green, while, tunica muscularis (M) stained red. (Crossmon'strichrome, X 100)
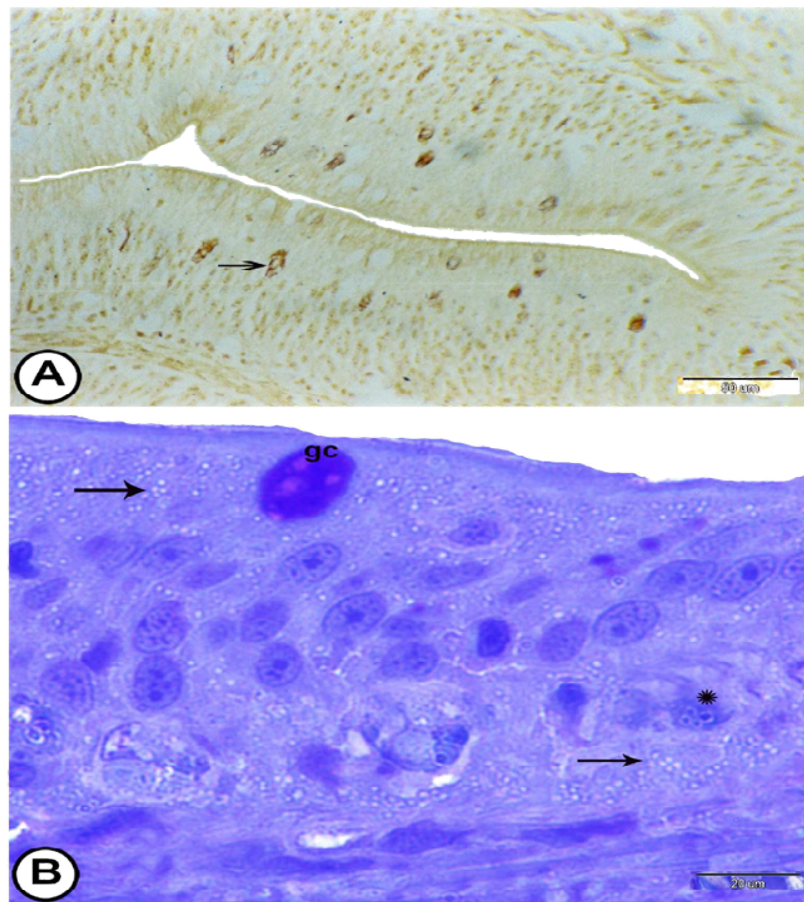

Figure 4: The constituent of the epithelium of posterior intestine: (A) Numerous enteroendocrine cells (arrow) are present among theenterocytes. (Grimelius silver stain). (B) Semithin section of simple columnar epithelium of the posterior intestineof grass carp showing positive reaction of goblet cells (gc). (C) Notice the presence of large number of vesicles (arrows) and cell proliferation $\left({ }^{*}\right)$ in the basal part of the epithelium. (Toluidine blue)

\section{Tunica muscularis}

It was a thin layer, consisted of inner circular and outer longitudinal smooth muscle fibers (Figure 3B). The mean thickness was 311.72 $\pm 2.66 \mu \mathrm{m}$ that constituted about $23.60 \%$ of the thickness of the wall (Table 1).

\section{Tunica serosa}

It was thick and composed of connective tissue that contained large number of thin elastic fibers and covered by mesothelium (Figure 3A).

\section{In semi-thin sections}

The enterocytes were tall and narrow, carried microvilli with oval vesicular nucleus. The cytoplasm of the enterocytes contained large number of larger vesicles than these in catfish, which might represent pinocytotic activity to some fluid nutrients. The rounded goblet cells gave positive reaction to toluidine blue. The intestinal epithelium represented a cell renewal system. Cell proliferation took place in the basal part of the mucosal folds (Figure 4B).

\section{Scanning electron microscopy}

The mucosa of the posterior intestine of grass carp was run in direction roughly perpendicular to long axis of the tube. The concavities between the folds were shallow (Figure 5A). The luminal surfaces of the epithelial cells were covered by microvilli and intercalated with largesized pores leading to mucous cells. At the meeting angels between several cells, large amount of mucus from underlying mucous cells were extruded (Figures 5B and 5C).

\section{Discussion}

In the present study, the epithelium of posterior intestine of grass carp revealed that it was consisted of simple columnar absorptive cells
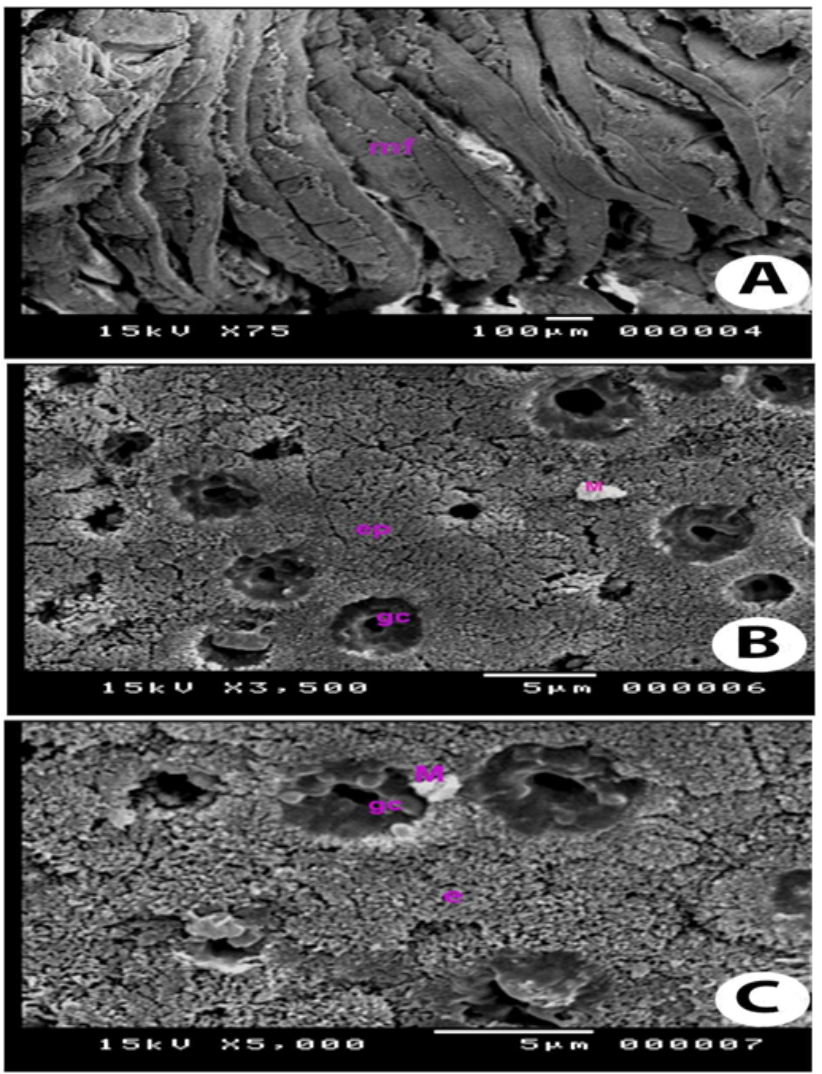

Figure 5: Scanning Electron Microscopy of mucosa of posterior intestine: (A) Scanning electron micrograph of the posterior intestine of grass carpshowing mucosal folds (mf) separated by concavities. (B) Scanning electron micrograph showing the closely packed epithelial cells(ep) with goblet cells (gc). Notice the presence of mucous droplets (M) on the surface. (C) Scanning electron micrograph of the enterocytes (e) of the posteriorintestine of grass carp, covered by microvilli. Notice the presence of large goblet cells (gc) and mucous droplets (M). 
(enterocytes) covered by microvilli, goblet cells, enteroendocrine cells and lymphocytes. The enterocytes was characterized by numerous large vesicles, which may represent pinocytotic activity to some nutrients.

The enterocytes are both absorptive and secretory in function [9]. The brush border contributes greater than $90 \%$ to total intestinal surface area in Tilapia aurea and T. zilli [10] and forms the critical digestive/absorptive interface, a functional microenvironment where enzymes involved in further food breakdown are located and where absorption and transport will occur. A number of enzymes like alkaline phosphatase, disaccharidases, leucine-aminopeptidase, and tri- and dipeptidases are localized to the brush border membrane in vertebrates including fishes [11].

Equisoain and Garrido [12] believed that most of animal protein was digested and absorbed in the middle part of intestine of carnivorous fishes (rainbow trout, cichlids and Oncorhynchus mykiss), whereas a constant rate of absorption had been demonstrated for plant protein throughout the whole intestine of the herbivorous fish (cyprinids).

Moreover, Deplano et al. [13] and Sklan et al. [14] stated that the abilities to absorb protein in the intestine of carnivorous fish are welldeveloped, but carbohydrate absorption is low compared to omnivorous and herbivorous fishes, while the absorption of protein is less developed in herbivorous fish. However the activity of pancreatic enzymes was maximal in anterior intestine and decreased distally. Leenhouwers et al. [15] detected some fermented bacteria in the posterior part of the intestine of carp, which supported that fermentation of carbohydrate occurs in the intestine of carp.

Although, Iida and Yamamoto [16] and Deplano et al. [13] reported the presence of pinocytotic vesicles and numerous vacuoles in the posterior intestine of both herbivorous and carnivorous fishes, which considered evidence of the uptake of undigested protein-like substances. This process begins by the proteins, which are incorporated into pinocytotic vesicles and transported to supranuclear vacuoles where they accumulate. The vacuoles were considered to be secondary lysosomes in which ingested proteins undergo enzymatic degradation, so proteolysis proceeds by intracellular enzymes. He added that in species having a stomach, the enterocytic pinocytotic vacuoles may be smaller. However, the formation of large vesicles in agastric species indicated a greater capacity for enodcytosis, perhaps in relation to less effective intraluminal digestion. Noaillac-Depeyre and Gas [17] added that absorption of protein by pinocytosis occur in the posterior intestine of carp and similar phenomena occur in suckling neonates of rat and mouse for absorption of immunizing protein from maternal colostrum and disappeared at $15^{\text {th }}$ to $21^{\text {st }}$ day postnatal when peptic secretion is developed. They stated that this type of absorption of macromolecules was related to the lack of complete extracellular digestion and the peptic secretion did not exist in stomach less fishes. In addition, the pancreatic trypsin, which is present in the intestinal lumen, does not produce complete hydrolysis of protein. The current work revealed presence of large number of goblet cells in posterior intestine, which were increased caudally. These observations were agreed with Sandhu [18] who explained that the presence of fewer mucous cells in the anterior intestine was probably because the need for lubrication of food was minimized in the anterior intestinal region, as it entered this region in semi-digested condition. Therefore, it can be suggested that excess of mucus in this region would weaken the digestive juices as well as impair absorption. The posterior intestine had more number of goblet cells for lubrication of undigested food materials for onward progression into the rectum. From the present investigation, it was observed that the goblet cells of posterior intestine of grass carp gave positive reaction to
PAS and Alcian blue, because of its contents of both acidic and neutral muco-polysaccharides. Their secretions may protect the delicate microvilli from mechanical injury and allow an easy transport of the ingested food materials. Similar findings were observed in Senegal sole by Arellano et al. [19] and Glyptosternum maculatum by Xiong [20]. They added that these muco-polysaccharides had many functions; it form a 8 diffusion barrier for various ions and fluids that allow their absorption, representing a physical barrier between mucosa and enzymatic agents, and also acted as co-factors of enzymatic hydrolysis. Our results indicated the presence of large amount of acid mucin in the posterior intestine of grass carp. Acid mucin in the posterior intestine of the herbivorous grass carp could facilitate the elimination of food residues. As we know, the digestion of plant nutrient food is supposed to produce more residues than that of animal nutrient food does. Acid mucus might be secreted after enzymatic secretions to prevent degradation of glycoprotein, it also amplifies the viscosity and adhesive properties of the mucus, which might assist the adsorption of watersoluble molecules and particulate food materials, and this is applied with Cao and Wang.

In accordance with the present study, it was clear that cell proliferation take place in the basal part of mucosal folds of intestine of both fish species, which cleared that the intestinal epithelium represented a cell renewal system. Similar findings were reported by Krementz and Chapman [21]. They added that the proliferation proceeds in waves through the intestinal mucosa, not simultaneous in all folds and the old epithelial cells migrated to the top of the folds where they are probably discarded. The renewal time of the intestinal epithelium in grass carp is relatively long (10-15 days). Leucocytes occur in all parts of the teleost's digestive system, most extensively in the intestine, where lymphocytes, plasma cells, granulocytes and macrophages are present in and under the epithelium. Although large lymphoid centers are lacking, many lymphoid cells, either scattered or in small groups were reported to be present in the epithelium and lamina propria, so that intraepithelial lymphocytes are necessary for a local or mucosal immune response [22]. Moreover, Deplano et al. [13] demonstrated presence of IgM in gut mucus of some fish species and they concluded that the posterior intestine contained lymphoid cells, macrophages and plasma cells between the enterocytes or in lamina propria, which indicate the existence of local immune system in the intestine. Gastrointestinal endocrine cells are distributed in the mucosa of the gastrointestinal tract and they synthesize various kinds of gastrointestinal hormones. They play important functions in the regulation of the physiological functions of the digestive tract. The existence of endocrine cells has been demonstrated in the gastrointestinal tract mucosa of different fish species [23]. Also they occur with the pancreas to constitute the Gastro Entero Pancreatic (GEP) endocrine system [24]. In the present study the lamina propria of anterior and posterior intestine of grass carp consisted of dense connective tissue contained collagenous and elastic fibers, in addition to blood capillaries. Dense collagenous lamina propria may support the intestinal epithelium. Fenestrated blood capillaries in the lamina propria of intestine may have a role in fluid and nutrients transport. These findings are applied with Ribeiro and Fanta [25]. Nachi et al. [26] observed that intestinal glands were absent in the intestine of all fishes except in 2 carnivorous fish species (Characiformes and Gadidae), which were consisted of columnar cells and goblet cells and had mucus secretory activity. Therefore, the origin of digestive enzymes in fish intestine is not evident as in higher vertebrates, but pinocytotic vesicles and well developed lysosomal systems could provide the intracellular digestion of foods. 
Citation: Mokhtar DM, Abd-Elhafez EA, Hassan AH (2015) Light and Scanning Electron Microscopic Studies on the Intestine of Grass Carp (Ctenopharyngodon idella): II-Posterior Intestine. J Aquac Res Development 6: 380. doi:10.4172/2155-9546.1000380

\section{References}

1. Pedini V, Scocco P, Radaelli G, Fagioli O, Ceccarelli P (2001) Carbohydrate histochemistry of the alimentary canal of the Shi drum, Umbrinacirrosa $L$. J Anat Histol Embryol 30: 345-349.

2. Petrinec Z, Nejedli S, Kuzir S, Opacak A (2005) Mucosubstances of the digestive tract mucosa in northern pike (Esox Lucius L.) and European catfish (Silurus glanis L.). J Veterinarski Arhiv 75: 317-327.

3. Marchetti L, Capacchietti M, Sabbieti MG, Accili D, Materazzi G, et al. (2006) Histology and carbohydrate histochemistry of the alimentary canal in the rainbow trout Oncorhynchus mykiss. J Fish Biology 68: 1808-1821.

4. Cunha AL, Pinto CB (2007) Ultrastructural, histochemical and cytochemical characterization of intestinal epithelial cells in Aplysia depilans (Gastropoda, Opisthobranchia). J Acta Zoologica 88: 211-221.

5. Diaz AO, Garcia AM, Goldemberg AL (2008) Glycoconjugates in the mucosa of the digestive tract of Cynoscion guatucupa: A histochemical study. J Acta Histochemica 110: 76-85.

6. Domeneghini C, Arrighi S, Radaelli G, Giampaolo B, Veggetti A (2005) Histochemical analysis of glyco-conjugate secretion in the alimentary canal of Anguilla anguilla L. J Acta Histochemica 106: 477-487.

7. Fiertak A, Kilarski WM (2002) Glycoconjugates of the intestinal goblet cells of four cyprinids. J CMLS 59: 1724-1733.

8. Bancroft JD, Steven A (1996) Theory and practice of histological techniques. $4^{\text {th }}$ Ed., Churchill Livingstone. New York. Edinburgh. London. Madrid. Melbourne. San Francisco. Tokyo.

9. Cyrino JEP, Bureau D, Kapoor BG (2008) Feeding and Digestive Function of fishes. Science Publishers, pp. xiii + pp 575

10. Frierson EW, Foltz JW (1992) Comparison and estimation of absorptive intestinal surface areas in two species of cichlid fish. Trans Am Fish Soc 121: 517-523.

11. Kuzmina VV, Gelman AG (1997) Membrane linked digestion in fish. Rev Fish Sci 5: 99-129.

12. Equisoain MA, Garrido MV (1996) Enterocytes in the anterior intestine of Oncorhynchus mykiss: Cytological characteristics related to osmoregulation. J Aquaculture 139: 109-116.

13. Deplano M, Connes R, Diaz JP (1991) Postvalvular enterocytes in feral and farm-reared sea bass Dicentrarchus labrax; hypervacuolization related to artificial feed. J Diseases of Aquatic organisms 11: 9-18.
14. Sklan D, Prag T, Lupatsch I (2004) Structure and function of the small 12 intestine of the tilapia Oreochromis aureus (Teleostei, Cichlidae). J Aqua Res 35: 350-357.

15. Leenhouwers JI, Pellikaan WF, Huizing HFA, Coolen ROM, Verreth JAJ, et at. (2008) Fermentability of carbohydrates in an in vitro batch culture method using inocula from Nile tilapia and common carp. J Aqua Nutri 14: 523-532.

16. lida H, Yamamoto $T$ (1984) Morphological studies of the goldfish hindgut mucosa in organ culture. J Cell Tissue Res 238: 523-528.

17. Noaillac-Depeyre J, Gas N (1973) Absorption of protein macromolecules by the enterocytes of the Carp (Cyprinus carpio L.). J Zellforsch 146: 525-541.

18. Sandhu AA (2000) Comparative anatomical and histological studies of the gastrointestinal tract of some fresh water catfishes in relation to their food (Pisces: Siluriformes). Ph.D, University of the Punjab, Lahore.

19. Arellano JM, Storch V, Sarasquete C (2002) Ultrastructural study on the intestine of Senegal sole, Solea senegalensis. J Appl Ichthyol 18: 154-158.

20. Xiong D, Zhang L, Yu H, Xie C, Kong Y, et al. (2010) A study of morphology and histology of the alimentary tract of Glyptosternum maculatum (Sisoridae, Siluriformes). J Acta Zoologica 118: 211-221.

21. Krementz AB, Chapman GB (1975) Ultrastructure of the posterior half of the intestine of the channel catfish, Ictalurus punctatus. J Morphology 145: 441 481.

22. Abelli L, Picchietti S, Romano N, Mastrelia L, Scapigliati G (1997) Immunohistochemistry of gut-associated lymphoid tissue of the sea bass Dicentrarchus labrax (L.). Fish. Shellfish. Immunol, 7: 235-245.

23. Diler D, Cinar K, Zorlu S. (2011) An immunohistochemical study on the endocrine cells in the stomach and intestine regions of the Dicentrarchus labrax, L., 1758. FU Sag Bil Vet Derg 25: 1-6.

24. Mokhtar DM (2015) Histological, histochemical and ultrastructura characterization of the pancreas of the grass carp (Ctenopharyngodon idella). Eur J Anat 19: 145-153.

25. Ribeiro CAO, Fanta E (2000) Microscopic morphology and histochemistry of the digestive system of a tropical freshwater fish Trichomycterus brasiliensis (lutken) (Siluroidei, Trichomycteridae). J Revta Bras Zool 17: 953-971.

26. Nachi AM, Blazquez FJ, Barbieri RL, Leite RG, Ferri S, et al. (1998) Intestina histology of a detritivorous (iliophagous) fish prochilodus scrofa (characiformes prochilodontidae). J Anna des Sci Nat 19: 81-88. 